\title{
INTERLEAVED, MULTI-SWITCH, MULTI-PHASE BOOST CONVERTER FOR BATTERY DISCHARGE REGULATORS
}

\author{
Fernando Sobrino-Manzanares, Ausias Garrigós \\ Industrial Electronics Group, UMH, Avda. De la Universidads/n (Spain),Email: augarsir@umh.es
}

\begin{abstract}
Non-isolated step-up voltage converters are commonly required as Battery Discharge Regulators (BDR's). The Weinberg and boost derived topologies are traditionally employed in modules up to one or two kilowatts. The Interleaved Boost Converter (IBC) is a distributed power processing approach that provides some advantages: reduced power processing (current) per phase, distributed losses (power semiconductors and magnetics), input and output current ripple cancellation, improved dynamic response and better modularity, among others. The IBC converter as BDR has been previously treated and advantages and drawbacks discussed. In this paper a new approach is proposed, a multi-switch, multi-phase interleaved boost converter (named Multi Interleaved Boost Converter, MIBC) that provides inductor and switching frequency decoupling, which in turn affects in different aspects, such as, magnetics, input and output current ripples or part count. This paper presents and describes the MIBC, the potential benefits compared to the IBC and its application as BDR.
\end{abstract}

\section{INTRODUCTION}

This paper is meant to be a general description of a PWM interleaved method for DC/DC converters. This modulation scheme is aimed to increase converter power density by combining number of modules (phases) in parallel and number of switches per module, please refer to figure 1 .

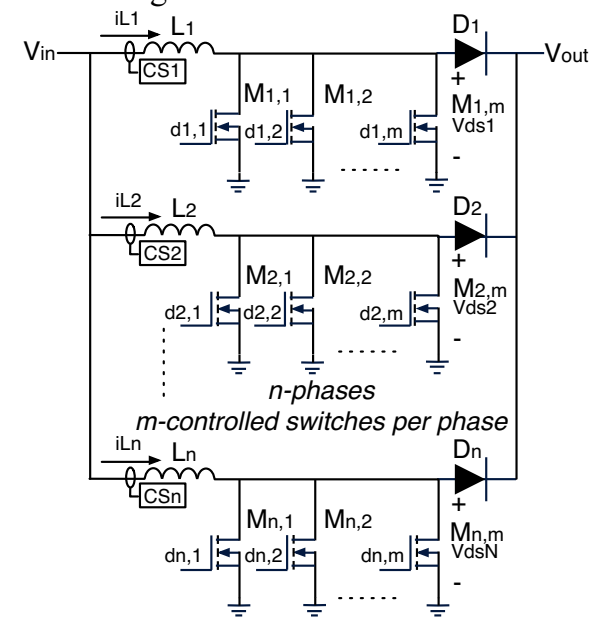

Figure 1. Multi Interleaved Boost Converter

\section{MIBC DESCRIPTION}

The MIBC has been devised using several multi-switch boost modules, which are out in phase [1]. Traditional multi-switch approach considers the same driving signal for all switches in order to divide the current into several power semiconductors being the reasons for that insufficient current handling capability, excessive power dissipation, complex thermal management or switch redundancy. In the MIBC, the driving signal of each power switch keeps the same switching frequency but the on-time is reduced by a factor $m$ and they are displaced each other in phase over $2 \mathrm{pi} / \mathrm{m}$ radians. This driving scheme decouples switching frequency and inductor frequency, which actually increases by a factor $m$. Also the common point, mosfet drain, has an effective switching frequency $m$ times higher than switching frequency. Another interesting feature is that only one switch conducts at a given time, so average current sharing could be adjusted by increasing the number of switches and decreasing the on time.

On the other hand, phase shifted paralleled modules, socalled interleaved converters, also offer reduction of input and output current ripple, improved dynamic response or power losses distribution, among other advantages. For the MIBC, modules will be displaced $2 \mathrm{pi} /(\mathrm{nm})$ radians.

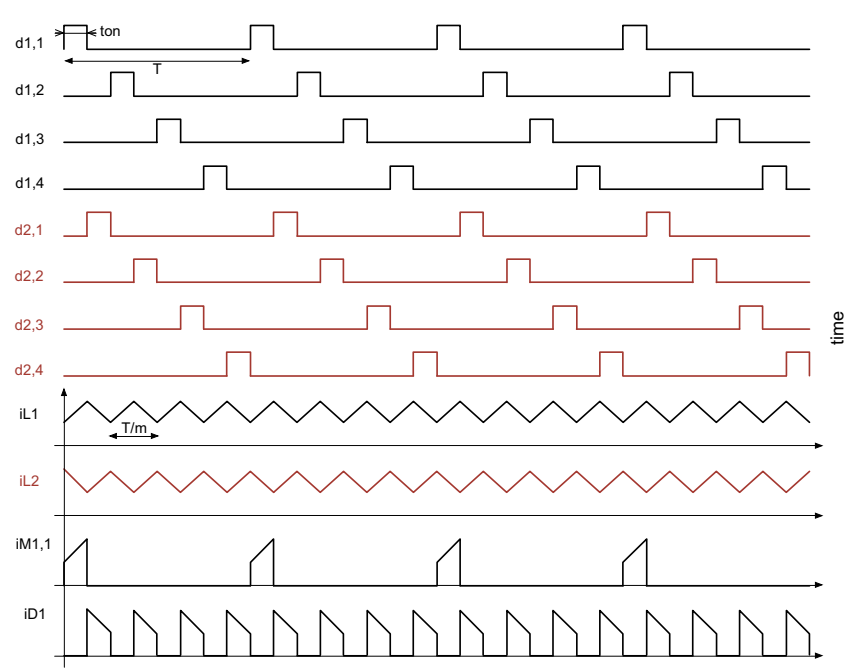

Figure 2. Sketch of the main waveforms of a 2-4-MIBC (2 phase, 4 switches per phase) 


\subsection{DC equations}

The MIBC DC analysis has been performed for the general ( $\mathrm{n} \times \mathrm{m})$ configuration. Main equations are listed in table 1 .

\begin{tabular}{|c|c|c|}
\hline Descrip. & Equation & $\mathrm{nb}$ \\
\hline Duty cycle & $D=\frac{t_{o n}}{T}$ & 1 \\
\hline $\begin{array}{l}\text { Voltage } \\
\text { conversion } \\
\text { ratio }\end{array}$ & $M=\frac{V_{o}}{V_{i n}}=\frac{1}{1-m D}$ & 2 \\
\hline $\begin{array}{l}\text { Inverse } \\
\text { voltage } \\
\text { conversion } \\
\text { ratio }\end{array}$ & $M^{\prime}=1 / M$ & 3 \\
\hline $\begin{array}{l}\text { Inductor } \\
\text { current } \\
\text { ripple (pk- } \\
\text { pk) }\end{array}$ & $\Delta i_{L}=\frac{1}{m} \frac{V_{o} M^{\prime}\left(1-M^{\prime}\right)}{L f}$ & 4 \\
\hline $\begin{array}{l}\text { Average } \\
\text { inductor } \\
\text { current }\end{array}$ & $\left\langle i_{L}\right\rangle=\left\langle i_{\text {in }}\right\rangle / n$ & 5 \\
\hline $\begin{array}{l}\text { Max. } \\
\text { inductor } \\
\text { current }\end{array}$ & $i_{L \max }=\left\langle i_{L}\right\rangle+\left(\Delta i_{L} / 2\right)$ & 6 \\
\hline $\begin{array}{l}\text { Min. } \\
\text { inductor } \\
\text { current }\end{array}$ & $i_{L \min }=\left\langle i_{L}\right\rangle-\left(\Delta i_{L} / 2\right)$ & 7 \\
\hline $\begin{array}{l}\text { RMS } \\
\text { inductor } \\
\text { current }\end{array}$ & $I_{R M S L}=\sqrt{\left\langle i_{L}\right\rangle^{2}+\left(\Delta i_{L}^{2} / 12\right)}$ & 8 \\
\hline $\begin{array}{l}\text { Inductor } \\
\text { frequency }\end{array}$ & $f_{L}=m f$ & 9 \\
\hline $\begin{array}{l}\text { Minimum } \\
\text { input } \\
\text { current for } \\
\text { CCM }\end{array}$ & $\left\langle i_{i n \min }\right\rangle=n \frac{V_{i n} D}{2 L f}$ & 10 \\
\hline $\begin{array}{l}\text { MOSFET } \\
\text { average } \\
\text { current }\end{array}$ & $\left\langle i_{M}\right\rangle=D\left\langle i_{L}\right\rangle$ & 11 \\
\hline $\begin{array}{l}\text { MOSFET } \\
\text { RMS } \\
\text { current }\end{array}$ & $I_{R M S M}=\sqrt{D} I_{R M S L}$ & 12 \\
\hline $\begin{array}{l}\text { Diode } \\
\text { average } \\
\text { current }\end{array}$ & $\left\langle i_{D}\right\rangle=(1-m D)\left\langle i_{L}\right\rangle$ & 13 \\
\hline $\begin{array}{l}\text { Diode RMS } \\
\text { current }\end{array}$ & $I_{R M S D}=\sqrt{1-m D} I_{R M S_{L}}$ & 14 \\
\hline $\begin{array}{l}\text { Ripple } \\
\text { cancellation } \\
\text { index }\end{array}$ & $R=M^{\prime} \bmod n^{-1}$ & 15 \\
\hline $\begin{array}{l}\text { Input } \\
\text { current } \\
\text { ripple (pk- } \\
\text { pk) }\end{array}$ & $\Delta i_{i n}=\frac{n}{m} \frac{V_{o}}{L f} R\left[\frac{1}{n}-R\right]$ & 16 \\
\hline $\begin{array}{l}\text { Input } \\
\text { (output) } \\
\text { frequency }\end{array}$ & $f_{\text {in }(\text { out })}=n m f$ & 17 \\
\hline $\begin{array}{l}\text { Output } \\
\text { RMS } \\
\text { current }\end{array}$ & $\begin{array}{l}I_{\text {out }}=\left\langle i_{\text {Rin }}\right\rangle=\sqrt{\left[\left(D_{e}^{\prime}-\frac{X}{n}\right)\left(\frac{X+1}{n}-D_{e}^{\prime}\right)\right]+\frac{n}{12 D_{e}^{\prime}}\left(\frac{V_{\text {in }} D}{L\left\langle i_{\text {in }}\right\rangle f}\right)^{2}} \\
{\left[\begin{array}{l}{\left[(X+1)^{2}\left(D_{e}^{\prime}-\frac{X}{n}\right)^{3}+X^{2}\left(\frac{X+1}{n}-D_{e}^{\prime}\right)^{3}\right]} \\
D_{e}^{\prime}=1-m D ; \quad X=\text { floor }\left(n D_{e}^{\prime}\right)\end{array}\right.}\end{array}$ & 18 \\
\hline
\end{tabular}

Table 1. DC equations of the general $(n \times m) M I B C$ converter

\subsection{Small-signal transfer functions}

Neglecting all parasitic elements, the small-signal transfer functions of the general ( $n \times x$ m) MIBC converter have also been obtained and listed in table 2 .

\begin{tabular}{|c|c|c|}
\hline Descrip. & Equation & $\mathrm{nb}$ \\
\hline $\begin{array}{l}\text { duty cycle- } \\
\text { to-output } \\
\text { voltage }\end{array}$ & $\begin{aligned} G_{v d} & =\frac{\tilde{v}_{o}}{\tilde{d}}=K_{v o / d} \frac{\left(1-s / \omega_{z}\right)}{\left(s / \omega_{o}\right)^{2}+s / Q \omega_{o}+1} \\
K_{\text {vold }} & =m V_{i n} / D_{e}^{\prime 2} ; \quad \omega_{z} \simeq n D_{e}^{\prime} R / L ; \\
\omega_{o} & =D_{e}^{\prime} / \sqrt{(L / n) C} ; \quad Q=D_{e}^{\prime} R \sqrt{(n C) / L}\end{aligned}$ & 19 \\
\hline $\begin{array}{l}\text { Duty cycle- } \\
\text { to-inductor } \\
\text { current }\end{array}$ & $\begin{array}{l}G_{i d}=\frac{\tilde{i}_{L}}{\tilde{d}}=K_{i L / d} \frac{\left(s / \omega_{z 1}+1\right)}{\left(s / \omega_{o}\right)^{2}+s / Q \omega_{o}+1} \\
K_{i L / d}=2 m\left\langle i_{i n}\right\rangle / n D_{e}^{\prime} ; \omega_{z 1}=2 / R C\end{array}$ & 20 \\
\hline $\begin{array}{l}\text { Inductor } \\
\text { current-to- } \\
\text { output } \\
\text { voltage }\end{array}$ & $G_{v i}=\frac{\tilde{v}_{o}}{\tilde{i_{L}}}=\frac{\tilde{v}_{o}}{\tilde{d}}\left(\frac{\tilde{i}_{L}}{\tilde{d}}\right)^{-1}=\frac{K_{v o / d}}{K_{i L / d}} \frac{\left(1-s / \omega_{z}\right)}{\left(s / \omega_{z 1}+1\right)}$ & 21 \\
\hline
\end{tabular}

Table 2. Small-signal equations of the general ( $n \times m)$ $M I B C$ converter

\section{COMPARATIVE STUDY: 8-IBC vs 4-2-MIBC vs 2-4-MIBC}

In order to evaluate and compare the MIBC and the IBC converters used as BDRs, a theoretical study has been carried out using [2] as the baseline specifications, please refer to table 3 .

\begin{tabular}{|l|l|}
\hline \multicolumn{2}{|c|}{ Comparative study: BDR main parameters } \\
\hline Po & $1.6 \mathrm{~kW}$ \\
\hline Vin $\min$ & $56 \mathrm{~V} \quad(\mathrm{mD}) \max =0.44$ \\
\hline Vin $\max$ & $94 \mathrm{~V} \quad(\mathrm{mD}) \min =0.06$ \\
\hline Vo & $100 \mathrm{~V}$ \\
\hline L & $50 \mathrm{uH}$ \\
\hline Co & $88 \mathrm{uF}$ \\
\hline fs & $125 \mathrm{kHz}$ \\
\hline
\end{tabular}

Table 3. BDR power module specifications for converter comparison

The study assumes the following, three configurations are evaluated: a) $n=8, m=1$; b) $n=4, m=2$; c) $n=2, m=4$. All have the same number of MOSFETs and consider the same parameters, listed in table 3 .

\subsection{Input \& output current ripple}

Substituting values in the equations (16) and (17) result in the input and output current ripples represented in figures 3 and 4. 


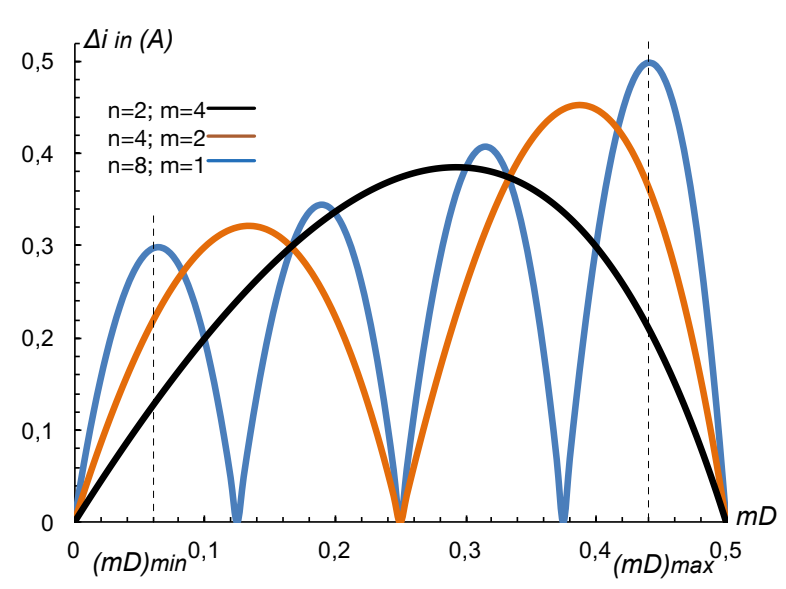

Figure 3. Input current ripple

As observed from figure 3, the 2-4-MIBC configuration exhibits the lowest input current ripple of all three. For certains $m D, 4-2-\mathrm{MIBC}$ and 8-IBC configurations have less input ripple, but at the extreme values of the duty cycle 2-4-MIBC performs better.

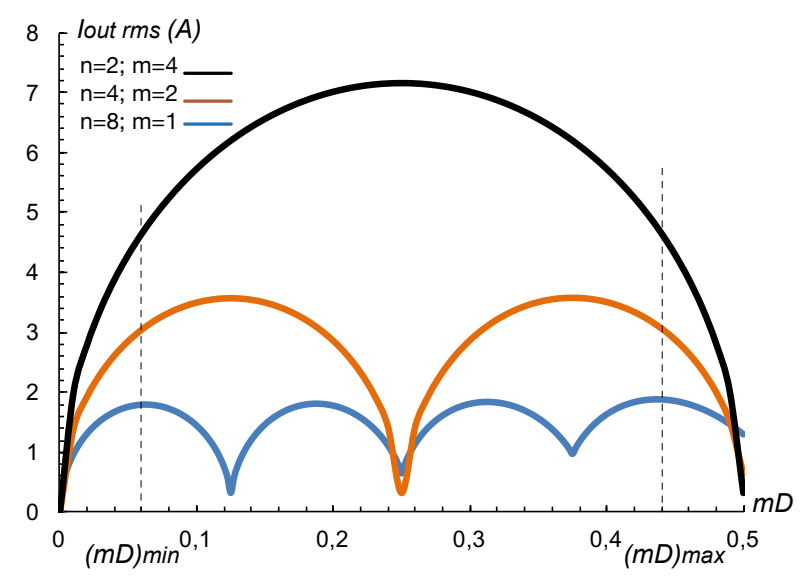

Figure 4.RMS output current (@Vin=56V,Po=1.6kW)

From the point of view of the output current, the 2-4MIBC has the highest RMS value in the whole range, which is a key parameter for output capacitor losses and voltage ripple. Thus, low ESR capacitors are mandatory to not impair MIBC performance.

\subsection{Inductor design}

Inductor design, using Magnetics toroid MPP cores, has been considered to evaluate size and volume reduction using MIBC. The inductor design considers Dmax and Po max, the same inductance value and switching frequency for all three configurations. The design procedure has been tuned to achieve similar inductor losses (global losses considering the sum of all inductors) and temperature increment. The most representative inductor parameters have been gathered in table 4.

\begin{tabular}{|c|c|c|c|}
\hline \multicolumn{4}{|c|}{ Comparative study: inductor design } \\
\hline & $\mathrm{n}=2 ; \mathrm{m}=4$ & $\mathrm{n}=4 ; \mathrm{m}=2$ & $\mathrm{n}=8 ; \mathrm{m}=1$ \\
\hline $\mathrm{Nb}$ of ind. & 2 & 4 & 8 \\
\hline Iavg & $14.2850 \mathrm{~A}$ & $7.1425 \mathrm{~A}$ & $3.5713 \mathrm{~A}$ \\
\hline$\Delta \mathrm{i}$ & $0.986 \mathrm{~A}$ & $1.97 \mathrm{~A}$ & $3.94 \mathrm{~A}$ \\
\hline $\mathrm{f}$ & $500 \mathrm{kHz}$ & $250 \mathrm{kHz}$ & $125 \mathrm{kHz}$ \\
\hline Core ref. & 55254 & 55929 & 55351 \\
\hline Turns & 22 & 21 & 34 \\
\hline $\mathrm{L}^{\mathrm{a}}$ & $0.051 \mathrm{mH}$ & $0.051 \mathrm{mH}$ & $0.051 \mathrm{mH}$ \\
\hline Ploss ${ }^{b}$ & $8.15 \mathrm{~W}$ & $4.31 \mathrm{~W}$ & $2.83 \mathrm{~W}$ \\
\hline$\Delta \mathrm{T}$ & $60.6^{\circ} \mathrm{C}$ & $62.1^{\circ} \mathrm{C}$ & $56.2^{\circ} \mathrm{C}$ \\
\hline AWG & 12 & 15 & 18 \\
\hline Win. fact. & $18.3 \%$ & $24.8 \%$ & $21.5 \%$ \\
\hline DC res. & $6.51 \mathrm{~m} \Omega$ & $9.58 \mathrm{~m} \Omega$ & $24.51 \mathrm{~m} \Omega$ \\
\hline Finish.OD ${ }^{\mathrm{c}}$ & $45.5 \mathrm{~mm}$ & $31.1 \mathrm{~mm}$ & $26.8 \mathrm{~mm}$ \\
\hline Finish.HT ${ }^{d}$ & $20.1 \mathrm{~mm}$ & $15.4 \mathrm{~mm}$ & $12.1 \mathrm{~mm}$ \\
\hline Area $^{\mathrm{e}}$ & $20.70 \mathrm{~cm}^{2}$ & $9.67 \mathrm{~cm}^{2}$ & $7.18 \mathrm{~cm}^{2}$ \\
\hline Mass & $128.8 \mathrm{~g}$ & $50.5 \mathrm{~g}$ & $27.6 \mathrm{~g}$ \\
\hline Total loss. & $16.3 \mathrm{~W}$ & $17.24 \mathrm{~W}$ & $22.64 \mathrm{~W}$ \\
\hline Total area & $41.4 \mathrm{~cm}^{2}$ & $38.7 \mathrm{~cm}^{2}$ & $57.4 \mathrm{~cm}^{2}$ \\
\hline Total mass & $257.6 \mathrm{~g}$ & $202 \mathrm{~g}$ & $220.8 \mathrm{~g}$ \\
\hline \multicolumn{4}{|c|}{$\begin{array}{l}\text { a) L at full load; b) Ploss per inductor; c) Finished Output } \\
\text { Diameter; d) Finished Height; e) Area as } O D^{2}\end{array}$} \\
\hline
\end{tabular}

Table 4. Inductor comparison

From table 4, 4-2-MIBC exhibits the best outputs in terms of total area and mass, 2-4-MIBC has the lowest losses and 8-IBC gives the poorest results in terms of losses and required size, bringing to light that MIBC offers less input ripple, less losses and less area and mass if compared to the traditional IBC.

\subsection{CCM/DCM boundary}

Another interesting feature concerns to CCM and DCM limits when MIBC is considered. As the number of phases and inductor frequency changes, the minimum inductor current also varies. Since boost transfer functions depend on conduction mode, the wider the range in a particular mode, the better from the control point of view. Analysing the three configurations, please refer to table 5, one realises that 2-4-MIBC requires the lowest output power to remain in CCM.

\begin{tabular}{|l|l|l|l|}
\hline \multicolumn{4}{|c|}{ Comparative study: CCM/DCM boundary } \\
\hline & $\mathrm{n}=2 ; \mathrm{m}=4$ & $\mathrm{n}=4 ; \mathrm{m}=2$ & $\mathrm{n}=8 ; \mathrm{m}=1$ \\
\hline $\begin{array}{l}\text { Iin min avg } \\
\text { CCM }\end{array}$ & $0.986 \mathrm{~A}$ & $3.94 \mathrm{~A}$ & $15.8 \mathrm{~A}$ \\
\hline $\begin{array}{l}\text { Pin min } \\
\text { CCM }\end{array}$ & $55 \mathrm{~W}$ & $221 \mathrm{~W}$ & $883 \mathrm{~W}$ \\
\hline
\end{tabular}

Table 5. CCM/DCM limit comparison

Table 5 reveals that 8 -IBC requires more than $880 \mathrm{~W}$ to work in CCM. In other words, 8 -IBC will work in both, DCM and CCM, in real conditions. On the contrary, 24-MIBC only requires $55.2 \mathrm{~W}$ to work in CCM; thus, problems related to DCM operation, like parasitic ringing or control loop design are virtually eliminated. 


\subsection{Power semiconductor stress and impact on losses}

An important concern regards to part electrical rating, subsequent part selection and converter losses. One of the most significant differences between the three configurations relates to conduction time and maximum current per switch. Regarding the power mosfet, reduction of both, phases and conduction time per mosfet, implies identical average current value, similar RMS value but higher peak current. Two important considerations arise from this fact, higher peak current capacity will be required and switching losses could increment substantially. Since all configurations will exhibit similar conduction losses, soft-switching techniques can be explored to keep similar performance. Regarding power diodes, one diode per phase is only required, but working at higher current level and $m$ times switching frequency. Parallel diodes could be also considered to split power losses.

\begin{tabular}{|l|l|l|l|}
\hline \multicolumn{4}{|c|}{$\begin{array}{l}\text { Comparative study: electrical rating } \\
\text { (Vin=56V, Vo=100V, Pin=1600W) }\end{array}$} \\
\hline & $\mathrm{n}=2 ; \mathrm{m}=4$ & $\mathrm{n}=4 ; \mathrm{m}=2$ & $\mathrm{n}=8 ; \mathrm{m}=1$ \\
\hline $\begin{array}{l}\text { Conduction } \\
\text { time }\end{array}$ & $0.88 \mathrm{us}$ & $1.76 \mathrm{us}$ & $3.52 \mathrm{us}$ \\
\hline $\begin{array}{l}\text { MOS avg } \\
\text { current }\end{array}$ & $1.57 \mathrm{~A}$ & $1.57 \mathrm{~A}$ & $1.57 \mathrm{~A}$ \\
\hline $\begin{array}{l}\text { MOS RMS } \\
\text { current }\end{array}$ & $4.74 \mathrm{~A}$ & $3.35 \mathrm{~A}$ & $2.34 \mathrm{~A}$ \\
\hline $\begin{array}{l}\text { MOS max. } \\
\text { current }\end{array}$ & $14.78 \mathrm{~A}$ & $8.13 \mathrm{~A}$ & $5.54 \mathrm{~A}$ \\
\hline $\begin{array}{l}\text { D.(Irms } \\
\text { mosfet)^2 }\end{array}$ & $2.47 \mathrm{~A}^{2}$ & $2.47 \mathrm{~A}^{2}$ & $2.49 \mathrm{~A}^{2}$ \\
\hline $\begin{array}{l}\text { DIODE avg } \\
\text { current }\end{array}$ & $8 \mathrm{~A}$ & $4 \mathrm{~A}$ & $2 \mathrm{~A}$ \\
\hline \multicolumn{3}{|l}{ Table 6. MIBC electrical rating }
\end{tabular}

\subsection{Small-signal transfer functions}

The MIBC small-signal transfer functions depend on both, $n$ and $m$ parameters. The number of phases, $n$, determines the equivalent inductance whereas the number of devices, $m$, has impact on the duty cycle.

Figures 5 and 6 represent the Bode plot of the smallsignal transfer functions $\mathrm{Vo} / \mathrm{d}$ and $\mathrm{iL} / \mathrm{d}$ obtained by the PSIM simulator for the configurations specified in the table 7 .

\begin{tabular}{|l|l|l|l|}
\hline \multicolumn{4}{|c|}{$\begin{array}{c}\text { Comparative study: small-signal transfer functions } \\
\left.\text { Vin=56V, }, \mathrm{V}_{\mathrm{o}}=80 \mathrm{~V}, \mathrm{Pin}=1024 \mathrm{~W}\right)\end{array}$} \\
\hline & $\mathrm{n}=2 ; \mathrm{m}=4$ & $\mathrm{n}=4 ; \mathrm{m}=2$ & $\mathrm{n}=8 ; \mathrm{m}=1$ \\
\hline $\mathrm{Kvo} / \mathrm{d}$ & $53.2 \mathrm{~dB}$ & $47.2 \mathrm{~dB}$ & $41.2 \mathrm{~dB}$ \\
\hline $\mathrm{fz}$ & $19.5 \mathrm{kHz}$ & $39 \mathrm{kHz}$ & $78 \mathrm{kHz}$ \\
\hline fo & $2.37 \mathrm{kHz}$ & $3.36 \mathrm{kHz}$ & $4.75 \mathrm{kHz}$ \\
\hline $\mathrm{Q}$ & 8.21 & 11.6 & 16.4 \\
\hline Kil/d & $40.4 \mathrm{~dB}$ & $28.3 \mathrm{~dB}$ & $16.3 \mathrm{~dB}$ \\
\hline $\mathrm{fz} 1$ & $579 \mathrm{~Hz}$ & $579 \mathrm{~Hz}$ & $579 \mathrm{~Hz}$ \\
\hline
\end{tabular}

Table 7. MIBC small-signal transfer functions
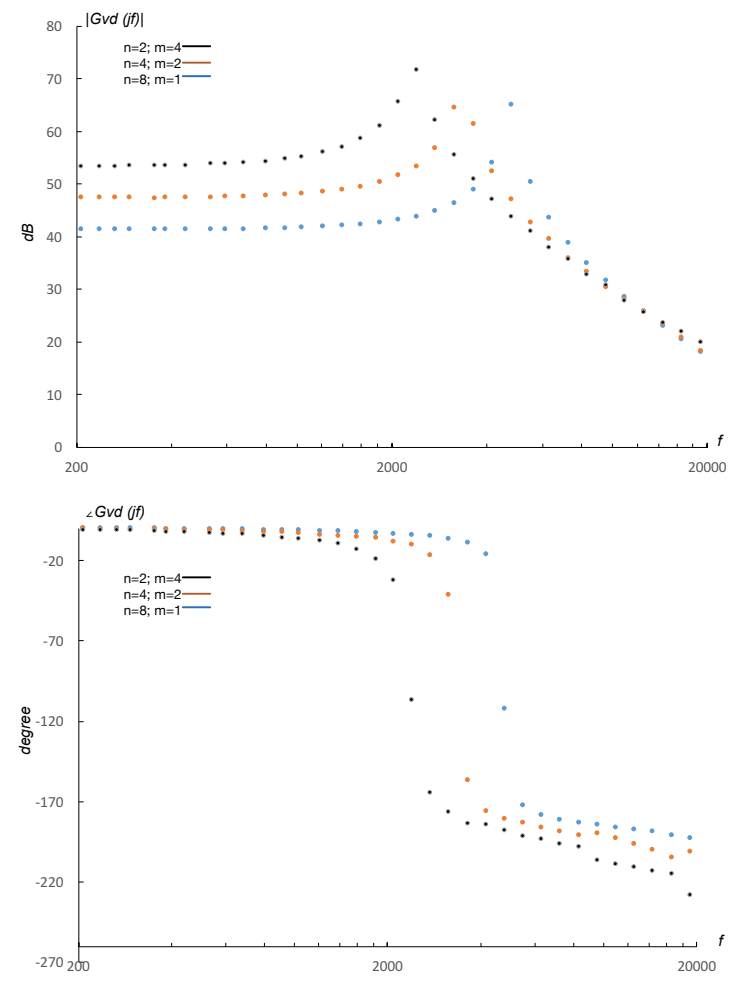

Figure 5. Duty cycle-to-output voltage transfer function. $P S I M$ non-averaged model ( Vin $=56 \mathrm{~V}, \mathrm{Vo}=80 \mathrm{~V}$, $P o=1024 \mathrm{~W})$
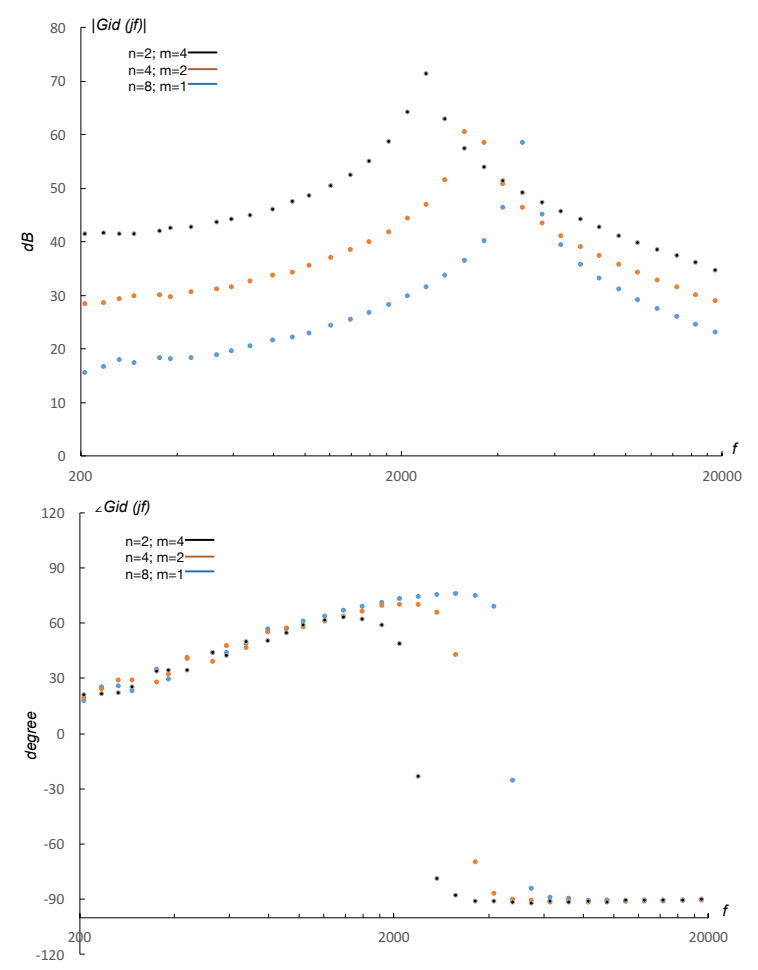

Figure 6. Duty cycle-to-inductor current transfer function. PSIM non-averaged model (Vin $=56 \mathrm{~V}$, $\left.V_{o}=80 \mathrm{~V}, P_{o}=1024 \mathrm{~W}\right)$ 


\section{MIBC SIMULATION}

Computer simulations using PSIM (Powersimtech) have been carried out to compare different configurations: a) $\mathrm{n}=2 ; \mathrm{m}=4, \mathrm{~b}) \mathrm{n}=4 ; \mathrm{m}=2, \mathrm{c}) \mathrm{n}=8 ; \mathrm{m}=1$, using the values of Table 3 .

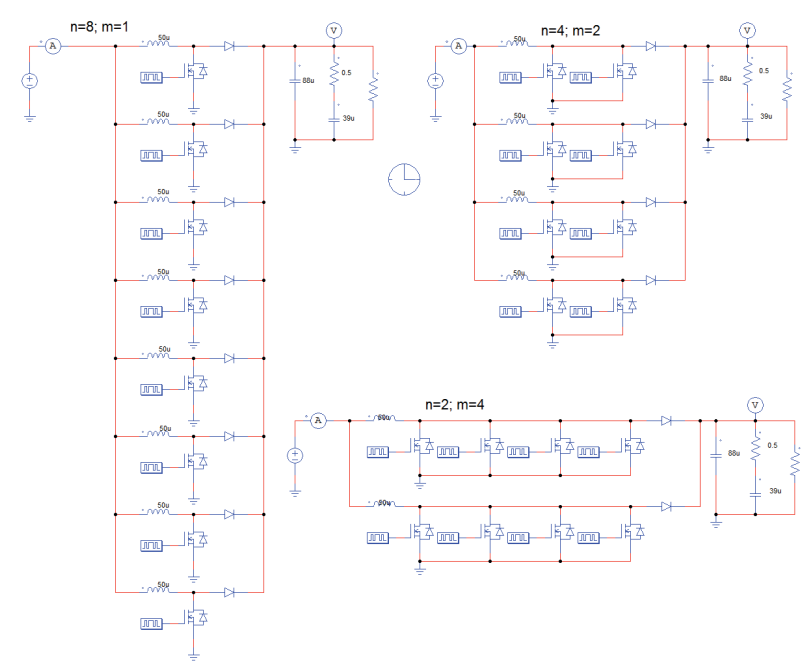

Figure 7. MIBC different simulation schemes.

Input current ripple at the minimum input voltage and maximum power for each configuration is represented in figure 8 . The lowest input current ripple corresponds to the $n=2 ; m=4$, according to (16) and figure 3 .

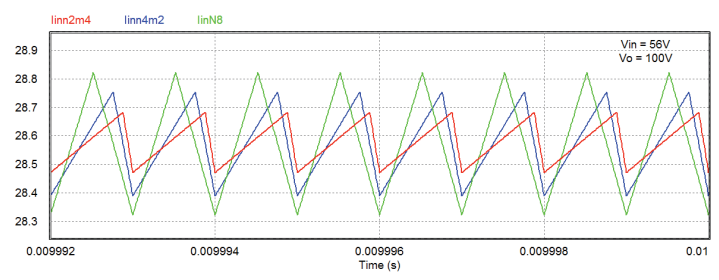

Figure 8. Input current ripple.

Output capacitor current at the minimum input voltage and maximum power for each configuration is represented in figure 9. The lowest RMS value corresponds to the $n=8 ; m=1$, according to $(18)$ and figure 4 .

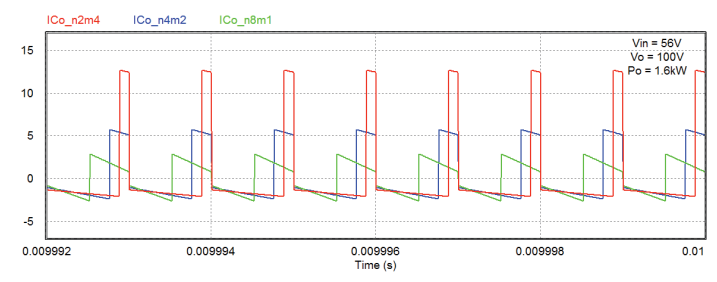

Figure 9. Output capacitor current.

$\mathrm{CCM} / \mathrm{DCM}$ boundary is represented in figure 10 . Considering a load resistor of 181.82 ohms
(55W@100Vo), only the $\mathrm{n}=2 ; \mathrm{m}=4$ configuration keeps in CCM operation due to higher inductor frequency. The other two configurations, in open loop mode, increase the output voltage because of DCM operation.

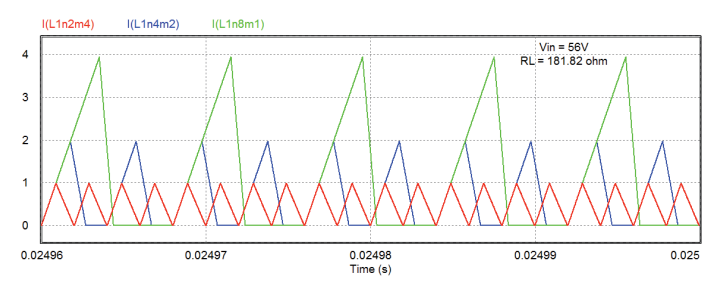

Figure 10. Input current ripple.

Mosfet current is depicted in figure 11. As it can be observed, the average value is the same for all configurations but the peak value and RMS value is higher as $n$ decreases.

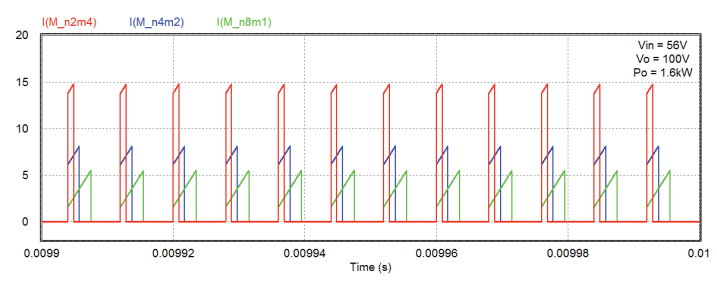

Figure 11. Mosfet current.

\section{MIBC: ANALOG PWM GENERATOR}

Two methods have been devised to obtain desired PWM signals for the MIBC. First method uses $n$ sawtooth signals and the control signal (Vc) splits into $m$ signals (Vci) with different offset (Voi), (22).

$$
\begin{aligned}
& V_{O i}=(i-1) \frac{V_{p}}{m} ; i=1 \ldots m \\
& V_{c i}=V_{c}+V_{O i}
\end{aligned}
$$

Simplified block diagram of the PWM generator for the 2-4-MIBC and the sketch of the main signals are depicted in figure 12.

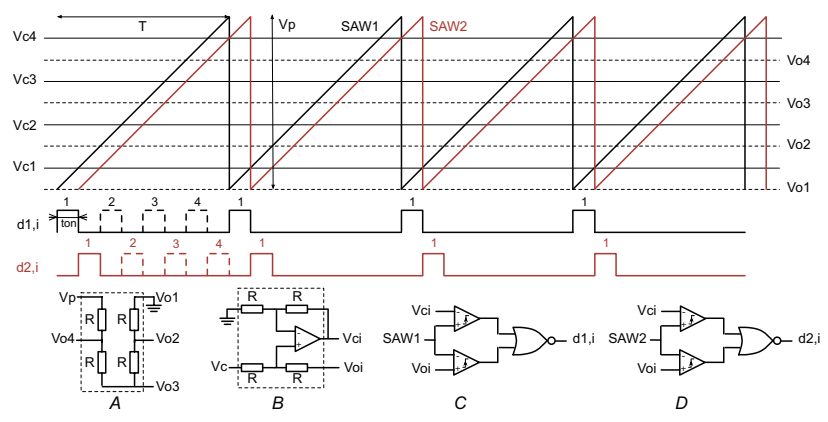

Figure 12. Analog PWM: option 1. 
Another option is to use $n \cdot m$ sawtooth signals and only one control signal, which is limited to $\mathrm{Vp} / \mathrm{m}$. Figure 13, shows the sketch of this analog PWM generator. Only one comparator is required for each driving signal.

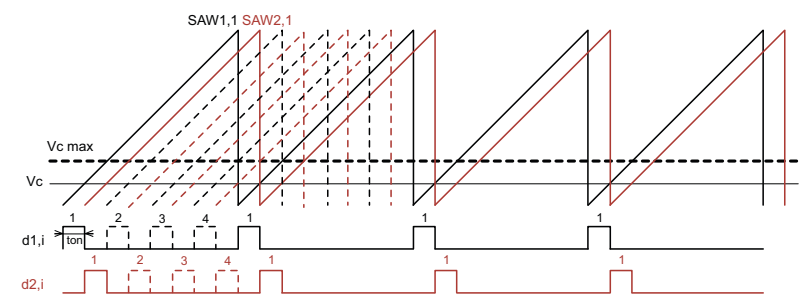

Figure 13. Analog PWM: option 2.

Figure 14 represents the PWM signal $(\mathrm{d} 1,1)$ and the sawtooth (SAW1,1) of one power MOSFET using the second method with the commercial multiphase integrated oscillator LTC6909 and a constant current source that charges a capacitor.

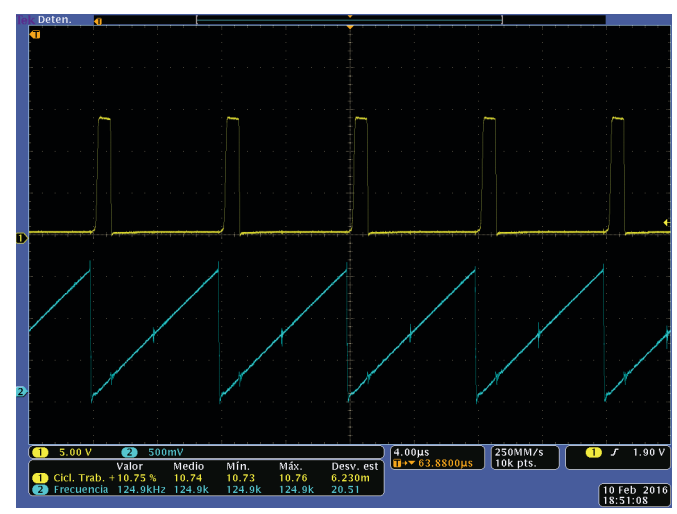

Figure 14. Sawtooth and PWM signal: option 2.

\section{MIBC: DIGITAL (FPGA) PWM GENERATOR}

Analog implementation of the PWM generator offers simplicity as the main advantage. On the contrary, digital approach, FPGA is considered here, is more complex but has some benefits that should be considered. To highlight some, high time resolution to achieve very low duty cycles, synchronous signals with adjustable dead time for bidirectional conversion or soft-switching, hot reconfiguration for redundancy, protection or efficiency purposes.

In this paper a digital PWM adapted from analog method option 1 is presented. Figure 15 shows the four gate signals of one phase switching at $96 \mathrm{kHz}$.

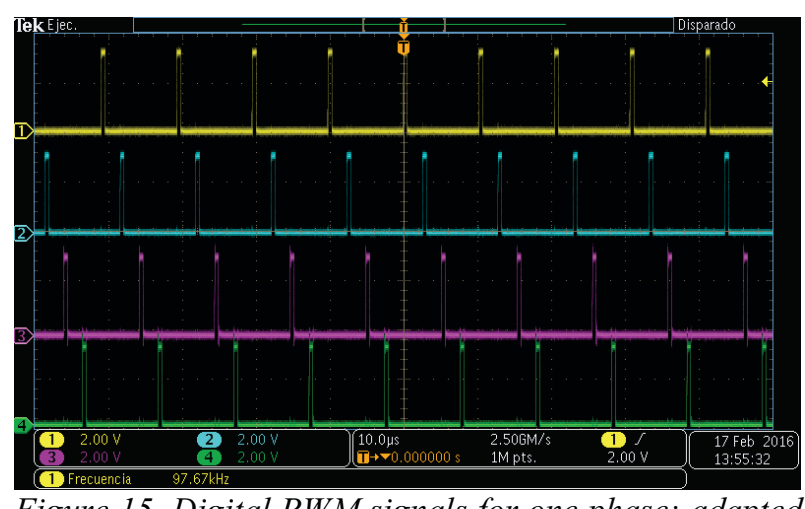

Figure 15. Digital PWM signals for one phase: adapted from circuit option 1.

\section{CONCLUSIONS}

This paper presents an interleaving technique that is suitable for DC/DC converters, BDR's is one possible application, as studied here, but other power conditioning functions could be explored. Design equations, comparative study and analog and digital (FPGA) practical implementation of the PWM generator system is presented.

\section{REFERENCES}

1. Hegazy, O., Van Mierlo, J. \& Lataire, P. (2012). Analysis, modeling and implementation of a multidevice interleaved DC/DC converter for fuel cell hybrid electric vehicles. IEEE Trans. Power Electron. 27(11), 4445-4458.

2. Carbonnier, H, Fernandez, A., Triggianese, M. \& Tonicello, F. (2014). Interleaved boost converter used as a battery discharge regulator for space applications, $10^{\text {th }}$ ESPC, Noordwijkerhout, The Netherlands. 